\title{
Inferential structures in old Romanian. The conditional and the concessive
}

\author{
Ștefan Găitănaru* \\ Faculty of Letters, University of Pitești, Str. Gh. Doja 41, 110253 Pitești, Romania
}

\section{Article info}

History:

Received February 12, 2019

Accepted March 5, 2019

Published May 7, 2019

Key words:

paradox

oxymoron

period

hypothetical

adversative

\begin{abstract}
The present study aims to highlight the fact that the conditional and concessive periods are two forms of manifestation of the hypothetical-deductive reasoning at the level of natural language. The evolution of the connectors has been described in diachrony, sometimes with the emphasis of the interference zones, with the semantic values imposed by the modal component of the predicativity and by the contextual determinism. The evolutionary analysis of the connectors has highlighted the fact that the old Romanian language, in order to impose the concessive procedural meaning, owns, like the other Romanic languages, a great area of creativity, but, unlike them, it also exercises its conservative character. The conception of the two syntactic relations as variants of the same system, studies the stylistic projection (the paradox and the oxymoron), the semantic and formal relation of the connectors and the implication of the adversative coordinating connectives in the polarization of the oppositions in the old Romanian language.
\end{abstract}

\section{Preliminaries}

1.1. In the diversity of statements there are, as in any language, also inferential statements that render certain types of reasoning at the level of natural language, due to the connection between language and thought.

Such a reasoning is the hypothetical-deductive or conditional one, which appears in the form of the adverbial modifier of condition, with a representation at the complex sentence level and, a less developed one at the sentence level.

More recent studies, starting perhaps from the similar periodic organization in Latin (subordinate clause / protasis + main clause / apodosis), have suggested a certain connection between conditional and concessive subordinates. Thus, the concessive is defined as "the exclusion of a ratio of conditioning (of inference) between two communication processes" (GALR II, p. 559).

It was also implied a relation between the two clauses and the causal subordinate: "concessive clauses (...) make up the negative sentences of the conditional and causal ones” (Ivănescu, 2004, p. 203).

It was even established that the most important group of concessive connectors, starting from the $16^{\text {th }}$ century, has been constituted according to "the conditional connector + focalizer pattern" (Zafiu, 2014, p. 211; cf. also Avram, 1960, p. 158). By virtue of this, some language history works have approached them under a common title (Conditionals and concessives), pointing out, each time, the interference zones (sor, p. 526-537).

It has also been shown that "the relation of the concessive with its regent term constitutes a paradox, because the difficulty expressed by the concessive conditional allows, and does not contradict - as it would be normal-the development of the action and the existence of the particularity in the regent clause" (Căpăţină, 2007, p. 261); and that "the global semantic value of this field subsumes to the notion of paradoxical connection” (Slușanschi, 1994, p. 60).

\footnotetext{
*Email address: stefan_gaitanaru@yahoo.com.
} 
Another challenge, offered this time by texts, is that many conditional and concessive clauses are coordinated (correlated) with the main clause (apodosis) by adversative conjunctions. Some authors, thinking about the situation in popular Latin, called them adversative adverbial clauses (Barbu, 1943, p. 138). But, as a matter of fact, the relation itself surpasses the subordination: "... in such complex sentences, the secondary clause is not actually secondary, but a sentence- subject, and the main clause is a sentence-predicate" (Ivănescu, 2004, p. 198). From which it can be deduced that it is about a bilateral dependence: "il n'y a ni principale, ni subordonné, mais interdépendence de deux propositions solidaires qui ne peuvent exister l'une sans l'autre et n'ont de sens que l'une par l'autre" (Ernout \& Thomas, 1964, apud Sluşanschi, 1994, p. 47).

In the same way, it was stated: "Logically, the relationship between the two sentences is a necessary ratio of implication between the subordinate and the main clause (...) the conditional sentence is not a mere element subordinated to the idea communicated in the main clause, but an element that necessarily determines the existence of the main sentence, whose idea is involved in the main clause" (Munteanu, 1998, p. 53).

1.2. The connection between the two syntactic positions as well as the understanding of the interference zones mentioned by grammarians can be revealed by a semantic-logical analysis of the type of implication assumed by these.

It should be emphasized that the conditional period is, in fact, a reasoning, a hypothetical-deductive inference. From this, one can come to the concessive period by a transfer of the protases from the positive variant of the inferential statement to the negative one. Therefore, we start from the following two variants: Dacă mă inviți, vin; Dacă nu mă inviți, nu vin. By changing the protases, one may have the following: Dacămă inviți, nuvin; Dacă nu mă inviți, vin. Unlike the condition, the concession represents an antonymic implication. So, in the structure of the hypothetical-deductive reasoning, the concession means either the denial of the hypothesis or the assertion of a negative conclusion (cf. GALR II, p. 592).

For the polarization of the opposition, in order to be constituted as a paradox, an intensive semiadverb (Zafiu, 2014, p. 211: focalizator [focalizer]) was added to the connector in the protasis, and in the precedence of the apodosis there appeared a concessive adverb (chiar, și - tot, totuşi): (Chiar/și) dacă mă inviți, (tot / totuși) nu vin; (Chiar /și) dacă nu mă inviți, (tot / totuşi) vin.

After some connectors acquired a procedural specific meaning in the evolution of language, the concessive could dispense itself of the prophrasic negation (cf. Dominte, 2003, p. 20) of the conditional period.

From a stylistic point of view, at the complex sentence level, one can speak of a paradox (cf. Dragomirescu, 1975, p. 170: Cînd nu s-ascundea nimica, deși tot era ascuns), and, at the sentence level, of an oxymoron (cf. Avădanei et al., 1994, p. 129) of the typevrînd, nevrînd; viu sau mort; de voie, de nevoie.

Grammarians have also pointed out the relation with the adverbial clause of cause (there is even an indirect or conditional causal subordinate). It has also been emphasized that most concessive connectors have other values, too: "conditional, causal, local or modal" (Avram, 1960, p. 158).

The causal value, as it will be seen, is one of the basic values of the hypothetical-deductive reasoning (conditional).

The existence of the polysemy of connectors, contextually determined, is normal in the unstable process of their specialization (cf. also Zafiu, 2014, p. 213).

The concessive ratio involves the concession to several elements of the statement, which is observed in the totalitarian relational connectors: the concession to the subject (Oricine vine, nu deschid), to the direct object (Orice aş mînca, mi se face rău), to other circumstantial values (oriunde, oricînd, oricum, oricit...).

These diversified aspects, preserved in diachrony, offer the image of a long process of formation and fixation of the syntactic structures of the inference in the literary Romanian language. 


\section{The complexity of the structure}

From the point of view of the way in which they were fixed in the written language, by the assumed techniques of the first two century traductology, more or less directly related to the structures evolved from the popular Latin, the two ratios (conditional and concessive) differ in terms of the degree of difficulty.

2.1. The hypothetical-deductive reasoning, because it represented a cognitive scheme, was part, in the configuration of syllogisms, of the basic, creative area of thought, representing its analytical capacity. But it implied a simple scheme, so the translators apparently took it (connector and structure) from spoken language (popular Latin). It is recorded as such also in other Romance languages (cf. the chapter Les Phrases hypothétiques commençant par si dans la langue française, des origines à la fin de XVI siècle in Wagner, 1966).

The simplicity of the syntactic scheme led to advantages and disadvantages. At the advantages there should be marked the normal frequency of the structure, resulting from the direct possibility of adapting, by translation, to the text-support. At the disadvantages it is mentioned the fact that all prototypical connectors (dac ăa, de and the etimological, să), did not acquire specificity, a fact which characterizes, as it will be seen, also the old Romanian language. Moreover, the only conditional adverb, altminteri, although it has been recorded ever since Coresi's translations (it is still encountered today), failed to impose by frequency, perhaps because at the sentence level, the syntactic position of the condition is in deficit compared to its manifestation at the complex sentence level.

2.2. The concessive period, the result of an antonymic induction involves a more complex cognitive scheme, and the result is a much reduced frequency. This fact was ascertained: "The sixteenth century texts offer, indeed, very rare examples of concessives. And it is not about a smaller proportion compared to other more frequent subordinates-a proportion that can be the same in the contemporary language-but it can be said that this species was less used" (Avram, 1960, p. 153). However, the author finds, in a parallel examination (the same text, different translations in time), big differences in the detriment of the $16^{\text {th }}$ century texts. There could be invoked several causes: the quality of translators; the existence of a large inventory of polysemantic connectors in Romanian language; the difficulty of understanding the syntactic pattern of the paradox type by receivers, from copyists to the beneficiaries of the message.

At a parallel examination, there are ascertained two attitudes. The first involves avoiding the structure, through a succession without specific connectors of the protasis and apodosis: De săară fi şi nedereptate fiind carea vă e obida așa rea, o, iudei, după cuvînt auzit ară fi voao sau să și întrebați... (СВ-CP, 195/3-5) Sefie nedireptate fiindu care cumva sau obidă rrea, după cuvîntu, amu, asculta fire-(a)șu voi sau se întrebari... (св, 195/3-5); fu de la Domnulpropovedire, spăsenie și înviere, deși ainte a morților înviere și a să judeca cu trupul (Св-СР, 297/3-4) - fu de la Domnului spunere spăsenie și îmviere. Și ceia ce înainte au murit... (св, 297/3-4); supuneți-vă bărbaților voștri, de și cine se va potrivi cuvîntului mueresc... (СВ-СР, 311/2-3) supuindu-se alelor săi bărbați, cel ce se potriveaște cuvîntului credincioasei mueri ( $\mathrm{CB}-\mathrm{CV}, 311 / 2-3)$.

It has been shown previously that the avoidance of the connector could be determined by the great inventory of the connectives. Indeed, for this century, there are mentioned an impressive number of 36 conjunctions (simple, compound, phrases) and adverbs: ca, că, căce, cum, de, să; de se, că să; să nu nici, să amu și...; măcară săa, măcară să și; dreptu căce, derep ce amu că să...; unde, de unde, io... (Avram, 1960, p. 154).

But, of the suggested examples (it is true that, inevitably, they are removed from the context) some seem to have only a weak concessive meaning (cf. also Zafiu, 2014, p. 13): Și cum era el fiiul lu Dumnezeu, pentru aceea ce se munci, cu sficiune învăța; Ca eu cu trupul acolo nu sînt, ce cu dubul, aceea judec că aceia ce aşa aceea au lucrat... să-l dați acela Satanei; Și amu de sînt ce se grăiesc dumnezei sau în ceri sau în pămînt, că sînt dumnezei mulți sau domni mulți, ce noi avem un Dumnezeu părinte (Avram, 1960, p. 154). 
Among the ones mentioned, there are also those which, in the tendency to specialize, dominate the others by frequency $(d e \ldots s, s i ; s \breve{a} . . . s i$, măcar și, măcar să...). This means that in the seventeenth century, the phenomenon of avoiding the concessive period through simpler structures no longer finds its motivation, whether the relation and the connector are kept, or only the relation: iară de am și știut pre Hristos după trup, iară de acum nu-l știm (NTB, 2Cor, 5, 16); iară de am și cunoscut trupeaște pre Hristos, iară acum nu-L mai cunoaștem (Bв, 2Cor, V, 16); Că de au și fost răstignit den slăbiciune, încă viiază den puterea lui Dumnezău (Nтв, 2Cor, 13, 4); Că măcară că s-au și răstignit din slăbiciune, iară trăiaște den putearea lui Dumnezău (вв, 2Cor, XIII, 4).

\section{The constitution of the semantic specificity (of the procedural meaning)}

An exact description of the circumstantial meaning should take into account that its matrix is represented by a correlative structure. As follows: the adverbial modifier of place (acolo..., unde), of time (atunci..., cînd), of manner (aşa..., cum); of condition (dacă/în caz că..., altminteri), of concession (chiar dacă..., totusi $i$. The adverb in the structure dominates the circumstantial substitution class, at the sentence level, and the connector dominates the class of the relational elements that initiate the subordinate clause at the complex sentence level.

The normative grammar does not consider such a semantic matrix to be the basic feature of an adverbial modifier and resorts to an optional recording. It sometimes records both elements: the adverbial modifier of place ("defining representation the adverbs unde (interrogative) / acolo" - GALR II, p. 514), of time ("defining representation the adverbs atunci, cînd" - GALR II, p. 495); of manner (așa, cum GALR II, p. 523). At the adverbial modifiers of cause, purpose, condition, concession, consecution, only the connectors are mentioned, while to the others, although questionably considered adverbial modifiers, the semantic structure is not mentioned.

The marking of both elements of the correlative structure is necessary because together they acquire a procedural meaning and thus provide the possibility to distinguish the objects from adverbial modifiers.

3.1. The conditional connectives belonging to the protasis of the conditional period depend from a semantic point of view on the structure of the hypothetical-deductive reasoning. It involves a relation of implication (logical consequence): Dacă e ziuă, afară e luminăa an inductive causal relationship: Dacă plouă, străzile sînt ude; an inertial implication ratio of one action by another: Dacă se face frig, aprind focul.

Since the absolute tenses of the indicative mood (present, compound perfect, and to a lesser extent the future) are deictic and have an accentuated epistemic modal component, the relationships between protasis and apodosis can be transposed as successions in time (Cînd e ziuă, afară e lumină; Cînd plouă, străzile sînt ude; Cînd se face frig, aprind focul) and as causal determinations (Fiindcă e ziuă, afară e lumină; Fiindcă plouă, străzile sînt ude; Fiindcă e frig, aprind focul).

This matter, which is valid for the contemporary language, was also valid for the old Romanian: "At the beginning, dacă had a weak conditional value, its main value being the temporal and the causal one" (Frâncu, 2009, p. 149).

The examples with temporal meaning are numerous, involving even the etymological connector: $S, i$ deca se sfirşiră aceastea, dzise lu Pavelu Dubul (cv, 4r/3-5); De trecură oarecare dzile, Agripa împăratu și Verrnichie deştinseră întru Chiesariia (cv, 34v/4-6); Să veri face bine, lua-veri plată (po, Bitia, 4, 7); Să tu de-stînga veri mearge, duce-mă-voiu eu de-a dereapta sau să tu în a dereapta veri mearge, eu în stînga voiu mearge (PO, Bitia, 13,9); E deca se adunrară ei, grăi cătră-nşii (СВ-СР, 261/1-2); și deca auzi norodul glasul trîmbițelor, au chiuit tot norodul (Bв, Navi, VI, 20); S, daca au înserat, l-au îmbrăcat cu haine proaste (GU, 77, 2/16-17); dacă s-au mai înglotit oastea s-au răsipitu cine încotro au putut (MC, 151, 1/25-27); Și dacă au audzit gîlceava la curte (...) au și purces spre curte (IN, 305, 2/25-27); Și dacă s-au făcut dzuă, s-au apropietu prin arini (IN, 306, 1/34-35). 
The connector dacă is sometimes repeated excessively at the beginning of the syntactic macrostructures so that it acquires a narrative functionality: Și daca au înserat, s-au întorsu înapoi. A doao zi dacă au aflat moldovenii că leșii au dat dos a fugi s-au lăsat după după dînșii a-i goni. Și daca i-au ajunsu... (GU, 102, 2/27-30); daca au biruit acea strajă (...) și daca s-au impreunat toți (...) daca s-au întorsu oastea lui Ion-Vodă (GU, 104, 2/2, 10, 25); daca i-au venit cărțile crăiești (...) Acolo daca au venit l-au aflat (...) daca au sosit la vad după el (GU, 109, 1/19, 22, 28); Deaca s-au dusu la gazda lui Ureche (...) iar dacă au aflat că vornicul au trecut Nistrul (...) iar dacă Ureche au trecut Nistrul (GU, 118, 1/23-32); Deaca văzu că muri Saul, luo și el sulița (...) deca văzură că au fugit oștile (...) deaca înțeleseră ce au făcut păgînii lui Saul, să sculară toți (INB, I, 29/11-14).

The causal value is equally well represented. As a rule, the indirect adverbial clause of cause, present also in the contemporary Romanian language, requires an interrogative or imperative apodosis, but, as it has been seen in the types of reasoning, it can also be declarative: Iară de greșindu muncă rrebdați, carea e laudă? (cv, 75 /6-8); Și de sîntem negrijnici, să părăsimu negrija. Și să sîntemu färă usîrdie, să fimu cu usîrdie ( $\left.\mathrm{CC}^{2}, 256 / 10-11\right)$; E deca se iuveaște adevărul piare minciuna (FD, 554 $\left.{ }^{\mathrm{v}}, 6\right)$; si deaca faci bine, nu-ți pară rău (INB, VIII, 211/14-15); să ceva va fi rămîiend, ardeți cu foc (PO, Ishod, 12, 10); Dară de ce botezi, deaca nu ești tu Hristos (NTB, In, 1,25); Să tu, fiind jidov, trăiești păgîneaște (...) pentru ce silești păgînii să săjidovească (Nтв, Gal, 2, 14).

Since, in the mechanism of determining the thought, the adverbial clause of cause was strongly connected to the adverbial clause of purpose (the original cause and the final cause), they were described together in the old grammars (Tiktin, 1945, p. 233). Independently of grammarians, however, in the old language, the conjunction $d e . . . s \breve{a}$ (with the subjunctive mood) shows the purpose clause, a situation which, with the indicative mood, occurs as a real purpose clause even today: Tremeaseră la elu de-lurrugară se nu-și dea sinre întru zborriște (CV, 5\%/10-11); dzise cu rrane se-lu întreabe elu de se îțteleagă dereptu care vină așa strigă spri-nsu (CV, 22 $\left./ 12,22^{\mathrm{v}} / 1\right)$; Și acealea scriem voao de și bucuria noastră să fie deplină (Св-СР, 327/1); Făgăduita ce ați auzit dentîiu, de să ne iubim unul la alalt (Св-СР, 355/4-5); Și aceaia iaste poruncita lui de să creadem în numele Fiiului Isus (СВ-СР, 359/1); și deade noao ințtelepciuni de să cunoaștem deadevărul (СВ-СР, 371/4, 5); de să nu piiardem ce-am lucrat (СВ-СР, 376/3, 4).

The constitution of the procedural meaning was understood by some specialists as an approach to the prototypical connector: "this conjunction (dacă, s.n.) gradually approaches more and more the conditional prototype that was once the conjunction să" (Frâncu, 2009, p. 49). But, as it can be seen from the examples, the etymological connector, when followed by the absolute tenses of the indicative mood, also expresses the real values of causality.

For an eventual assumption of the hypothetical (possible) or unrealistic meaning, other indicative tenses and other moods (conditional with its two tenses) had to be used. According to the denomination of the reasoning ("hypothetical-deductive or conditional"), it can be deduced that these two values are specific to the conditional period, the real conditional being difficult to delimit from the contextual determinism. Maybe that is why the normative grammar mentions also the future in its structure, it being part of the absolute tenses of the verb: "It is considered a proper conditional clause the subordinate which, in the hypothetical period, specifies a process via the indicative forms (present, past and future)" (GALR II, p. 587).

Instead, the use of the potential forms of the verb can confer the status of a conditional connector to other relatives, as well, which, normally, have another syntactic destination: "Quite often, the conditional clause is a sentence introduced by cind (...) when the mood of the verb (both in the regent clause and in the subordinate clause) is the conditional mood: Așa cum insuşi Alfieri nu s-ar fi tradus mai bine, cînd ar fiștiut românește" (SLR, p. 344).

Hence the idea that "specific to the conditional sentence are dacă and de" (SLR, p. 43); "However, most of the time, the conditional sentence is introduced by dacă (or by its synonym de), which is consequently considered to be the typical connector of the conditional sentence" (GALR II, p. 82).

But the character of specificity (the assuming of the procedural meaning) and the frequent usage are 
different things. Thus, dacă and especially, de can introduce, in the old language, a variety of subordinate clauses: (attributive clause) sîntu cu-rusul meșteri de au către neştinre cuvîntu (cv, 6\% /13-14); grămădi Pavelu vițe de vie multe de le punrea spre focu (cv, 48v/2-3); (adverbial clause of purpose) Intrămu de vînslămu și nă apropiem de Chipru (cv, 12 2 /11-12); (direct object clause) Judecă măriia-ta, ca un domn creștin, de iaste cu cale și de să cuvine să fu lipsit acuma, la bătrînețele mele, de amîndoao (AI, 230/24-26).

The conditional sentence (assumed by the speaker as real) with the verb in the protasis in the future is frequent: De veri vrea, poți mă curăți (Св, 435/5-6); De veri zice să vie, ea are a veni $\left(\mathrm{CC}^{2}, 251 / 21\right)$; de veri adeveri și veri avea muiare necredincioasă nu veri scăpa de nevoe (MO, 137 $/ 4-5)$; Că de ați creade lui Moisi, doară ați creade și Mie (...) iară să nu veți creade scripturile lui, cum veți creade cuvintele Meale? (NTB, In , 5, 46); de nu-ți va fi grijă de poruncile lui Dumnezeu, nici vei băga în seamă învățătura mea (INB, $\mathrm{I} / 20$ ); Ii va da numai de-i va birui (GU, 74, 1/16); de nu-l va rădica și din țară și din domnie îl vor scoate ei cu oaste (GU, 76, 2/14-15); De vii vrea, vii putea (CI, 74/16-17); Deaca veți întra în cetate, aşa îl veți afla

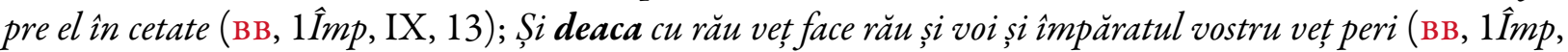
XII, 25); De vei fi în ziua aceasta rob norocului acestuia și vei sluji lor și vei grăi cătră ei cuvinte bune, vor fi tie robi toate zilele (BB, 3Împ, XII, 7).

However, the hypothetical conditional sentence, introduced by dacă, de and $s \breve{a}$, in which the conditional meaning is not questioned, is equally frequent: $\boldsymbol{S e}$ ară, amu, intra întru gloata voastră bărrbatu... intra-va și mişelu intru scîrnave veșminte (СB-Cv, 274/5-7); $\boldsymbol{S}$-ară Domnul vrea și, amu, a fi vii să facem ceasta sau ceaia (СВ-СР, 289/3); Și să ară fi aibînd păcate, lăsa-se-vor lui (СВ-СР, 294/2); Es-am zice că nu greșim, minciune face-vrem (Св, 329/1); Că de-ară avea credință desăvîrșitu cătră Dumnezeu n-ar fi așa grijindu-se neîncetatu ( $\left.\mathrm{CC}^{2}, 243 / 20-22\right)$; de așu mearge în mijloc de bănat, învie-me-veri ( $\mathrm{PH}, 117^{\mathrm{r}} / 16-$ 17); de nu s-ar hi prilejit o samă de capete să cerce mijloace... ar hi fostu de perire de istov țara aceasta (MC, 153, 1/24-26); de s-aru mai întoarce Duca-vodă, ei să nu vie cu dînsul (IN, 302, 2/5-6); de-ar hi lăsat pașa să margă tătarii după dînșii... puțini ar hi mersu cu dobîndă (IN, 465, 2/38-39); de nu ar hi perit el, nici într-un chip nu ar fi luat turcii acea izbîndă (RG, 109/13-14); De s-ar fi potrivit domnul faptelor lor (...) de viață s-arfi lipsit (RG, 131/36-37).

The unreal value, as a frequency, does not coincide with the reduced frequency of the perfect conditional, of the imperfect and of the past perfect simple of the indicative mood: Es s-am zice că nu greșim, minciune face-vrem (Св, 329/1-2); De te-ai teame de ruşine, n-ai grăi aşa (FD, 592 /6-7); Că de-ară avea credință desăvîrșitu cătră Dumnezeu n-ar fi așa grijindu-se neîncetatu ( $\left.\mathrm{CC}^{2}, 243 / 20-22\right)$; de nu s-ar hi prilejit o samă de capete să cerce mijloace... ar hi fostu de perire de istov țara aceasta (MC, 153, 1/24-26); de-ar hi lăsat paşa să margă tătarii după dînșii... puțini ar hi mersu cu dobîndă (IN, 465, 2/27-32); de nu ar hiperit el, nici într-un chip nu ar fi luat turcii acea izbindă (RG, 109/13-14); Că de-ași fi fostu în statul puterii mele, armasariul așe tare nu m-ar fipurtat și de-așifi fost de vitioan așe de iușor, atîta de sus nu m-ar fi rădicat (CI, 95/2-6).

Despite the great number of variants (ca, de, deca, deaca, daca, dacă, să, se, de...; cf. sLR, p. 257-258) the conditional connector did not succeed until the $19^{\text {th }}$ century to acquire a procedural meaning, to have an exclusive occurrence in the conditional protasis, as it happened with many concessive connectors.

It seems that this was a necessity in language, since, when the area of communication was expanded, the phrase in caz că (for the concessive, chit că) was taken from French.

The conditional connector is indeed specific: "The definitive realization of the adverbial modifier of condition is the conjunctive sentence introduced by $\hat{i n}$ caz că" (GALR II, p. 582). It is explained by the abandonment of the attributive determination of the noun (în cazul cind, în cazul că) by disarticulation: in caz că (cf. Iordan, 1954, p. 504; Avram, 1960, p. 196). Taken around 1700 (cf. DELLR, p. 79), as a Latin-Roman neologism, the noun $c a z$ was used as a support in many more or less merged phraseological groups: în cazul acesta, în orice caz, în tot cazul, în cazul cînd...(cf. DLRLC, p. 351). It is interesting that, among these it is also the prepositional phrase în caz de and the conjunctive phrase in caz căa, both of them with conditional usage, expressing, in fact, not the condition, but the hypothesis (cf. Munteanu, 1998, p. 54). 
In a normal order of things, since an adverbial clause is the expansion at a complex sentence level of an adverbial modifier (the adverbial modifiers had been called in the old grammars adverbial complements (cf. Drăganu, 1945, p. 91) there has to be identified the adverb with the conditional meaning. It is about the adverbs altminteri and altfel (cf. also Iordan \& Robu, 1978, p. 675), which substitute a negative protasis: Dacă mă inviți, vin; Dacă nu mă inviți (altminteri) nu vin (cf. also GALR II, p. 89).

It is rarely encountered in the old language: $E$ acmu nu oprește, ce amintrileaș tăriia sa arată mai mare (apud Frâncu, 2009, p. 198; CC² , 308); Și aimintrea iară iaste minunată (apud Frâncu, 2009, p. 198; CC CC $^{2} 342$ - cf. și ILRL, p. 157); Lorențu Topeltin, den Mediiaș, sas de-amintrilea, iară om învățat și destul umblat (ITR, 36 $\left./ 10,36^{\mathrm{V}} / 1\right)$; era tînăr de zile, amintrilea era om mînios și pre lesne vărsa sînge ( $\mathrm{GU}, 73$, a, 24-25).

However, it should be emphasized that the adverb from the semantic matrix of the conditional does not establish with the clause that it resumes a relationship of coreferentiality. Thus, in a statement of the type Unde veri ceti leage, acolea-i umbra legei ce-au trecut (VO, 20v/17-18) we have a coreferent adverbial clause of place (other studies call it apposition, without involving in its denomination the nature of coreferentiality). Instead, in a statement of the type Dacă plătești, ți-o dau, altminteri $n u$, between the protasis and the adverb altminteri it is not a direct correlation, but a negative one (altminteri $=$ dacă $n u$ plăteștie), which points to the paradox of the concessive structure. This explains why some grammarians have also mentioned altminteri in the syntactic position of the concessive (Frâncu, 2009, p. 370).

Because the prepositional phrases that could express an adverbial modifier of condition (in locul, in caz de) appeared later, the expression of the position is often performed by the gerund: Aibind Fiiul Zeului, are viață, neaibînd Fiiul Zeului viață n-are (Св-СР, 369/2-3); au scris la pașe ... să-i sloboadă oamenii, că, neslobodzindu-i, s-antoarce cu tot obuzul înapoi (IN, 465, 2/24-25); Dar cum ar fi putut face bine sau rău nefiind el? (INB, I, 11/9); voi să nu-i ascultați, văzînd că aceia au putere mai multă decît voi (INB, VIII, 211).

3.2. The concessive connectives have a clearer trajectory in the process of acquiring the procedural meaning. Their diversity, as a plurality of attempts, does not surprise, given the abstract and paradoxical character of the logical relation they express. Instead, it is the high percentage of their specialization, starting from the old Romanian language,that impresses.

Although there circulated the idea that "In Romance languages it was ascertained the loss of concessive connectors, whose main sources were written according to (1988, p. 76) the indefinite, the volitional and the temporal pattern" (Zafiu, 2014, p. 212) this is questionable at least for Romanian language. It is true, the paradoxical connection of the concessive had in classical Latin several reportings: the concession to hypothesis (ut/ne); to causal or temporal determinism (cum); to comparison (quamquam, quamvis, quamlibet), but also to conditioning (cf. Slușanschi, 1994, p. 60). The latter apparently had a higher productivity in popular Latin: "A fairly well-defined area is that of the conditional concessives, opened by $s i$ or its compounds (...) the clear marking of the concessive value of the subordinate clause is given by the compound conjunctions etsi, și dacă, tametsi și etiamsi, chiar dacă” (Slușanschi, 1994, p. 60). It should be mentioned that in classical Latin, in texts (as in the subsequent grammars), the elements of the compound conjunctions appeared also unagglutinated as in the old Romanian language: "Les propositions concessives sont elle qui commencent: a) Soit par si (suivie dans la propositions principales, de tamen), ou par etiam si, et si” ... (Riemann, 1932, p. 378), with certain semantic differences („etiam si ou et si signifiant quand même; etiamsi, ou etsi signifiant quoique", Riemann, 1932, p. 378).

It seems that the most common pattern of the concessive functioned without too many changes in the popular Latin, since we encounter it identical in old Romanian: și-l va rădica Dumnedzeu și s-are hi făcut și păcate, ierta-să-vor lui (Vo, 8 $/ 9-10)$; și se n-are fi dzăcut cu nusa nu poci a me însura cu nusa că mi se prinde îmă (Prav.1581, 229v-230 , apud Stan, 2013, p. 254); cătră el trage pre noi și săn-am vrea noi, dulcele Dumnezeul nostru ( $\left.\mathrm{CC}^{2}, 262 / 17-18\right)$.

Sometimes, only the order of elements differs: să și n-avămu a trupului boalăa, iară inima noastră de 
pururea e păzită (CC², 433/17-18); Și acolo iară să și bucate multe și în multe chipure să sîntu, însă puţinu stau inainte ( $\left.\mathrm{CC}^{2}, 291 / 17-18\right)$.

The etymological forms are also found (Lat. et si - Old Rom. e să): $\boldsymbol{E}$ să amu și aceluiași Dumnezeu inchinară-se, că crezură Samareanii și iudeii, însă Samareanii nu știia $\left(\right.$ CC $\left.^{2}, 161 / 4-6\right) ;$... e să mie nu veți crede, lucrului mieu credeți (Ст, 209-210, apud Avram, 1960, p. 155).

That is why, some theories of creativity, at least those referring to the Romanian language, must be at least partially reconsidered: "Romanian, like the other Romance languages, lost the Latin concessive markers (the only exception could be măcar 'even') and rebuilt new conectives, sometimes using the same pattern" (sOR, p. 534).

However, the correlative structure expressing the adverbial modifier of concession in contemporary Romanian (chiar dacă..., totuşi / etiam si..., tamen) is related to the same lexical creativity of the Romanian speakers.

One can certainly discuss about continuity because what was said about the Latin conditional concessives can also be said about the Romanian ones: "The most important as a frequency is the group of conjunctions that have come to introduce concessive clauses starting from their conditional value" (Avram, 1960, p. 158), thus continuing a concessive pattern: conditional connector + focalizer (cf. Zafiu, 2014, p. 211).

The Latin conditional connector $s i$ (Rom. să/se), although it still keeps both values in the contemporary Romanian (Să am bani, mi-aș lua mașină; $\boldsymbol{S} \breve{a}$-mi dai un milion, nu ți-o arăt) did not succeed, neither in the conditional period nor in the concessive period, to acquire a procedural meaning.

In emphatic way, it was used alone in Latin: Si bona fortuna veniat, ne intromiseris (TL, p. 41; cf. Sluşanschi, 1994, p. 60). But the phenomenon is encountered, as it was seen, not only in the contemporary Romanian, but also in the old Romanian language: nu veriscăpa de nevoe, s-ai lăcui în turnul Semireanului, să ai fi ingrădit cu foc (MO, 137 $/ 5-6)$. Such a context proves that Romanian concessive conjunctions are not "all of them formed with elements inherited from Latin on the territory of the Romanian language" (Frâncu, 2000, p. 209).

The discontinuous connectors seem to have a higher intensive value (the intensifiers had a deictic behaviour), since, especially in the inherited pattern, the structures are frequent: $s a ̆ a t i$-ar fi și tată și mumă macară, feciorii macară să ți-ar fi, deaca se află pizmaşii legiei lu Hristosu, să ne potrivimu și noi loru (cc ${ }^{2}$, 225/1-3); iară să va și grăi așa de sineși și va mărturisi că are puteare, nicio mărie nu-i iaste ( $\left.\mathrm{CC}^{2}, 280 / 1-2\right)$.

The discontinuity became much more frequent after the replacement of $s a ̆$ with $d e$. The phenomenon was due to the homonymous coincidence of $s e(=$ dac $\breve{a})-s e$ (reflexive pronoun) or in the variant achieved by intensification: $s \breve{a}-s \breve{a}$ ("the necessity to avoid the construction să săva", Arvinte, 2004, p. LXII). As the difficulty was general, the area of change was bigger and certainly older, culminating with the exemplary texts: "When they prepared the text (BB, s.n.) for printing, the Bucharest old correctors, the Greceanu brothers, "modernized" it, that is, they adapted it to the southern literary norm, the Wallachian one, systematically replacing, in all occurrences, the conjunction $s \breve{a}$ 'dacă, with the conjunction de" (Arvinte, 2004, p. LXII). The result: "the conjunction $s \breve{a}$ 'dacă' disappeared from the norm of the modern literary language at the end of the $17^{\text {th }}$ century" (Arvinte, 2004, p. LXII).

The preference for this connector can also be seen from the much higher frequency in the discontinuous structure: de... și: De să ară fiind și nedreptate fiind carea vă e obida aşa rea (СВ-CP, 195, 3-4); de te și grijești, ome, și să și socotești, nemică nu veri face, deaca nu va vrea Dumnezeu (cc² , 242/18-19); Că de au și fost răstignit den slăbiciune, încă viiază den putearea lui Dumnezău (NTB, Cor, 13, 4); Că de v-am și intristat pre voi cu cartea mea, nu mă căiesc, să m-am și căit (...) v-au intristat pre voi (NT B, Cor, 7, 8); iară de or și prăda-o, nemic n-a hi decît să le ie ienicerii muierile (IN, 288, 2/13-14); carele lucru d-ar fiși fost (...) nici o laudă, nici o cinste n-ar fi fost ( $\left.\mathrm{AB}, 118^{\mathrm{v}} / 3-4\right)$; Și de sînt și rob, astăzi am căzut în robie, iară tu ești rob de cînd te-au făcut tată-tău (AB, 121 v/41-42); De au și fost vreo jiganie rea, dulăul au gonit-o (CI, 89/5-6).

As it has been shown, there is a great number of alofunctives of the concessive connector, in express- 
ing the different values, determined by the modalities imposed by the predicate and by the diversity of contexts, between real, potential (conditional) and unreal. Besides the ones exemplified above, there are many more, each of them with many variants, covering, as it can be seen from the examples, the first three centuries of Romanian written culture.

Although it is not very frequent, deși appears even from the beginning when formal experiments with the other connectors were being unfolded: fu de la domnul propovedire, spăsenie și înviere, deși ainte a morților înviere (Св-CP, 297/3-4); Iară, deși ai tu, nu te lăuda, că de la Dumnezeu le-ai luat (INB, I, 8/32, 9/1); că deși era răpit la vremea sa, iară nu îndelungu (MC, 169, 1/20-21); Ce de și oblicie Antonievodă încă nu le dzice nemic (IN, 299, 1/3-4); Deși vedzi cîndva sămn groaznic să nu te miri (VO, 1v/1-2), Deși înaintea oamenilor cazne au pățit, nedejdea lor de nemoarte plină iaste (CD,73/15-16); că, deși peste tot și tuturor glasul Corbului iaste neplăcut, avem între noi Coțofana (CI, 55/11-12); că, deși tăcerea, intre noi iubitorii înțelepciunii lăudată iaste, însă la vreme de treabă icoana neștiinții arată (CI, 104/4-5).

Considered "the oldest and the most stable concessive connector (or component of some concessive connectors) in Romanian” (Zafiu, 2015, p. 678), the junctive based on măcar has the most interesting evolution, starting with the popular Latin, which took it from Greek ( $\mu \alpha x \alpha \dot{\rho} \rho)$ ), continuing with the Balkan and Romanic languages. At the level of the formal configuration, it has a great availability, from the simple adverb to the hyperfunctional one. But this did not save it from regression because "Starting from the second half of the nineteenth century, the concessive connectors containing it have been replaced in the standard language by other connectors fully or partly grammaticalized" (Zafiu, 2015, p. 678).

When it appears alone, the adverbial value opposed to altminteri is more stressed: Măcar sărac, măcar mişel, cu multă multă mulțumire să laude pre Dumnezeu (INB, I, 30/22-23); împăratul, cît de mult setos fiind, măcară mulțime de izvoară avea (Bв, Iosip, 3/22-24); partea trupului cea roditoare, carea în cevași macară betejindu-se, de grabnică moarte aducătoare iaste (CI, 23/10-13); Ce măcară noi, sau îngerul din ceriu va propovădui voao altă (...), anatema să fie (NTB, Gal, 1, 8); nimic alt n-au mai căutat, măcar un salam malichim de la musaip să auză ( $\left.\mathrm{AB}, 130^{\mathrm{V}} / 44-45\right)$; pe legheoanele romane, carii de curînd era adaose acolo, nu le-am putut piiarde, măcară între varvari cufundați era (ITR, 72\% /12-13).

This intensive semiadverb functioned as an intensifier alongside very numerous conjunctions: Să pue domn strein, măcar și din feciorii de domn ce era la Țarigrad (AB, 114²/48-49); Măcar și de șapte ori de va greși fratele tău (...) iartă-i lui (NTB, 93 15 -6); pentru ce a nenumărată a lor mulțime, măcară că era pren țară cei mai mulți (B , 2Mac, 736, b, 47-48); lucrul său îl știia purta, macară că era tînăr de zile (GU, 73, a, 23-24); s-au aședzat la domnie măcară că era de mare credință la împărățiie (MC, 153, a, 11-12); pasire iaste, măcară că carnea la gust îi iaste ca a delfinului și măcară că precum prin aer cu slobozie poate umbla (CI, 26/8-10); Măcar să acei boieri era greci, dar să pune tare pentru țară (IN, 278, a, 2-3); nimeni să nu să amăgească și să să ție mare, măcar să fie impărat, măcar domnu, măcar boiariu, măcar fiește ce va fi (INB, I, 43/8-10); Măcar de s-ar și pleca noao, de ce treabă ne-ar fi noao sau pardosu măcar de ar fi și blìndu (INB, I, 12/18-19); Măcar de vei birui, măcar de te vor birui, aceia tot să fie lîngă tine (INB, VIII, 217/19-20); Și măcară casă de să va împărți pre sine, nu poate sta casa aceaea (BВ, Mc, III, 25); Măcar de v-aru și poronci domnul, atunce... (IN, 299, b, 1-2).

There are, however, other associations that were not subsequently imposed in the language. One of these is the redundant association: Iată, măcar deși grăiaște de făpturi, iară de ingeri nu pomeneaște (INB, I, 23-24); nici să se obrăznicească în biruințele lor a-i lăsa, ci, măcar deși lega cîteodată cu ei pace... (ITR, 11\%/10-11); Măcar deși ceva bun cu darul lui Dumnedzău de la tine au ieșit, nu te, pentru aceasta cu sufletul inălța, nici te cu firea îmfla (CD, 132\%/19-21); că măcar săvai că iaste și tras în nevodul sventei evanghelii, săvai că iaste și în beserecă cu credincioșii $\left(\mathrm{VO}, 158,223^{\mathrm{r}} / 14-15\right)$.

Neither the constructions with relators had the chance to impose: măcară cît am ostenit, cît am cercat, cît am întrebat... (ITR, 2 2 6-7); măcar cum mai mult dobitoacelor în patru picioare asemănîndu-te... (CI, 21/11-12); macarcare, macarcine, macarîncotro, macarunde (DVL, p. 201-202).

Some connectors did not resist in the language although they were frequent in a certain period. An example is the construction săvai (să-vrea, să-vreai - săva, săvai) obtained on the Romanian territory. 
It was claimed to have appeared in the seventeenth century (Stan, 2013, p. 256), but, as the examples show, the adverb săva, besides other values, had also imposed a concessive meaning ever since the previous century: săva fie nămearnic de laturi, săva lăcuitoriu de aicea sufletul aceluia va pieri (PO, 12, 19); săva bou fie, săva asin, săva oaie de doao orisă dea atîta (PO, 22, 4); săva bou fie, săva asin, săva oaie săva veșmînt, săva aceacea ce-ai pierit ( $\mathrm{PO}, 22,9)$.

Later, the concessive adverb, exactly the one which was close to the etymological form, was associated with other connectors, assuming full concessivity: am putut și greși, săva că am silit de cît am putut să nu greșim (NTB, Pred., 116); scrisără și ei evanghelii, săva că au fost și alții mulți care eu scris evanghelii (NTB, Pred., 118); nu fuiu mai mic decît apostolii cei mari, săva că nemică sînt (NTB, Cor, 12, 11).

The other variant close to the etymological structure occurs rarely, evolving to săvai, being often associated with various connectors: săveri că-mi era mie poarta deșchisă pren Domnul, nu avuiu răpaos sufletului mieu (NTB, FA, 2, 12); săvai că foarte cu durere dă inemă și întristăciune la toți (...) atît carele cît și oamenii, în fermanu poruncea (RG, 256/3-4); au purces arătînd grabnică gătire (...) săvai că pornirea le-a fost numai mănioasă și groaznică ( $\left.\mathrm{RG}, 326^{\mathrm{v}} / 3-4\right)$; au fost de fel dacu, săvai că forte puțini rămăsease (ITR, $21^{\mathrm{r}}$ ); săvai vii, săvai deaca murim, a lui Dumnedzeu sîntem (Vo, 31 ${ }^{\mathrm{v}}$, 13-14); Săvai de ți s-ar ruga vrăjmașul cu glas mare, să nu-l asculți (Bв, Sol, XXVI, 25); Și săvai de cătră împuțînarea vîrtutei să va opri a păcătuit, de va afla vreame a face rău (BB, Inț, XIX, 24); Că săvai și mai multu de mă voiu lăuda pentru putearea noastră (...) nu mă voiu ruşina (Bв, Cor, X, 8).

The semantic matrix of the concessive period (chiar dacă... totuşi) was totally achieved from the beginning: Căci care viețuiescu întru bunătăți oare să voru avea bogăție, oare meserătate, totuși e lucru bunu și cu spăseniia și bine ( $\left.\mathrm{CC}^{2}, 27-29\right)$; să ș-ai arunca această în trei părți, de chinu născătoare, totu împotrivă află-se săgetarea ei ( $\left.\mathrm{CC}^{2}, 11-13\right)$; să și scapă aceia înșişi de aceaia, iară ai loru moșteani totuşu au cu aceaia a se chinui și a se osindi ( $\left.\mathrm{CC}^{2}, 500 / 21-23\right)$.

The relation between the adverbial modifier and the corresponding clause is provided by the configuration of the relative subordinate, since the relative connectors also fulfil the syntactic function.

But the adverbial modifier of concession is better represented than the conditional one. Sometimes the correlative is also present: Cîte răutăți facem, iar Dumnezeu tot ne invrednicește cu cinste (INB, I, 11/10-11); Și orîncătro și spre ce vrăjmași de ai tăi vei merge, tot îi vei birui și-i vei pune suptu picioarele tale (INB, I, 19/10-11).

The pattern of the prepositional group (in ciuda, in pofida, in pizma, impotriva) had not yet been grammaticalized (cf. Frâncu, 1977, p. 15-26): să nu gîndiți că doară pre voia cuiva sau în pizma cuiva (...) s-au scris (IN, 266, a/16-17); iar amintrile (...) în pizma adevărului socoti (CI, 46/16-18); pre ciuda lumii aceasta din pricinele firești de amănuntul să o ispitim (CI, 117/14-15); Împotriva a toată socoteala driaptă, gîndul și fapta Corbului pre cît mai mult putu a abate sili (CI, 130/4-5).

The construction dominated by adverbs is quite frequent: toate le-au chivernisit săvai cu dăstul pas săracilor (RG, 142 /1); măcară domni, măcară bogați, măcară săraci, tot greșim lui Dumnezeu (INB, I, 5/22-23); măcar numai cu o poruncă a lui Dumnezeu (INB, I, 16/14-15); carea în cevaş măcară betejindu-să de grabnică moarte aducătoare iaste (CI, 23/3-4); lacomul, și sătul flămînd iaste (CI, 39/34). In similar structures, the conjunction deși (deși sărac...), involves the ellipsis of the copula, placing the construction at the complex sentence level.

The relative connectors, represented by the totalitarian indefinite (pronouns / pronominal adjectives and adverbs) frequently introduce the concessive clause in old Romanian language: vare ce vrem ceare pre voia lui, asculta-va noi (СВ-CP, 370/1-2); Oricîte va greși fieștecarele aproapelui său (...) să-i dai calea lui in capul lui (Bв, 3̂̂Imp, VIII, 31); I-au poruncit ori cu ce mod va ști, oamenii lui să trimiță să-l prinză (RG, 173 $/ 3-4$ ); oricît va cheltui pentru dînsul, îi va întoarce mai cu asupră cheltuiala (GU, 91, a/1-2); Și ori la cine și ori la ce boieriu mergea cu carte, în picioare sta boieriul pînă să citiia cartea (MC, 169, b/10-12); iară acel omu împărătescu, cine-r hi fostu, au dat samă c-au vădzut (IN, 284, b/16-17); Ori în ce parte vor merge vor prăpădi tot și să vor întoarce (RG, 191 $/ 12)$; de mi-are face doftoriul să fie bărbatul mieu cu mine, ce mi-are ceare eu t,-oi da (s, 97 $/ 22-24)$. 
If at the complex sentence level the concessive period is, in fact, the expression of a paradox; at the sentence level, the correspondent is an oxymoron. It consists in the meaning obtained by neutralizing an affirmation through an antonym: Dulce e somnul robului, săvai puțintel, săvai mult va mînca (B B, Ecl, $\mathrm{V}, 11$ ); unde va fi domnul mieu impăratul și săvai la moarte și săvai la viață că acolo va fi robul tău (B В, $1 \hat{I} m p, \mathrm{XV}, 22)$; Și aşa turcii, de voie, de nevoie, le-au căutat a sta de război (RG, 123²/12-13); Nu să cade să omori niciunul, ori cu vină, ori fără vină ( $\left.\mathrm{s}, 86^{\mathrm{r}} / 17-18\right)$; să-l rrădice ori cu voe, ori fără voe, cum vor ști (RG, 329/6-7); ori dă voe să zicem, ori dă nevoie a primi, le-au căutat ( $\left.\mathrm{RG}, 344^{\mathrm{v}} / 6-7\right)$.

Frequent are the verbal ones: ce vrea să-şi astupe ruşinea veri neveri (MC, 170, b/43-44); Si iată că dintr-adunările voastre vrînd-nevrînd, îm caută a lipsi (CI, 26/3-4); pre carea și vrînd și nevrînd î va căuta a merge (CI, 124/20-21).

\section{Other features common to the two syntactic positions}

Besides the content aspects (the connection between the conditional and the concessive at the level of the hypothetical-deductive reasoning) and those of form (obtaining the basic concessive connectors by focalizing the conditional ones), there are also other aspects in the interference zone of the two syntactic positions: the type of formation of some important connectors, the incidence of adverbial correlatives, and the possibility of amplifying the periods at the discourse level.

4.1. As a way of composing, there will be analyzed the agglutination, which primarily engages the conjunction de, of an uncertain etymology. There are often given formal equivalents from the Slavic environment (Ciorănescu, 2001, p. 281).

The polyfunctional character gives it special importance. At the level of the current norm, it can control 5 syntactic relations, even if they have specific connectors (conditional, causal, concessive, final and consecutive) (cf. MDA, II, p. 27-28).

The different values of this conjunction do not differ from those of its compounds, as described above. Clearly, conditional sentences remain those in which the predication is achieved through the relative tenses of the indicative and the conditional: Că de ați creade lui Moisi,doară ați creade și Mie (NTB, In, 5, 46); n-ar hi fostu färă răscoală de nu s-ar fi späimat Racoți (MC, 188, b/31-32).

The conjunction de shows a great disponibility to form compounds by agglutination: (deaca, deca, daca) dacă; deși, deci, decît etc.

The typical conditional connector dacă was obtained from the simple connector $d e$ and the adverb $c a$ (Lat. quam, cf. Old Sl. jako) in the virtue of the fact that in certain contexts they had similar values: de= îndată ce, imediat ce, după ce, cînd, cît timp; ca = cînd, îndată ce, după ce (cf. Arvinte, 2004, p. LXI).

As in the case of $d e$, the functive $c a$ was polyfunctional, "what can also be noticed with the help of the equivalences that are established between the different used forms (when this happens) in the compared versions" (Gafton, 2001, p. 157).

In most correlations, the probable equivalence is made with deca: iară ca lu îmvise elu din morți nu după aceaia vruindu se întoarce întru putredire (св, 143/2-3) - E deaca-l invise el den morți, de-aciia acela nu vru a se întoarce în putredire (СВ-CР, 143/2-3); Și ca giudecatu fu se nutămu noi întru Italia (CB-CV, 244/6) - Ce ca se judecă fu noao a nota întru Taliia (СВ-СР, 244/5) - Deca judecat fu a nota noao întru Italie (Св, 244/6); Ce ca văzură păgînii spînzurînd șarpele de mîna lui, grăiră unul cătră alaltu (СВ-CР, 257/1-2) - Deci deca vădzură varrvarii spîndzurîndu șarrpele de mînra lui grăiia urul cătră alaltu (CB-CV, 257/1-2).

The formal variants of dacă (cf. Gafton, 1999, p. 95-101) had a relative dialectal distribution. Moreover, in $\mathrm{BB}$, in which the northern area was represented by Mitrofan, Dosoftei's envoy, and the southern part by the Greceanu brothers, there are encountered: și deca auzi norodul glasul trîmbițelor au chiuit tot norodul cu chiot mare (вв, Navi, IV, 21-23); Și să făcu deca să suiia zorile şi chemă Samuil pre Saul (Bв, 1 Împ, IX, 27-28); Deaca veți întra în cetate, așa îl veți afla pre el în cetate (Bв, 1 Împ, IX, 13-14); Și deaca cu rău veți 
face rău, și voi și împăratul vostru vețperi (Bв, 1̂̂mp, XII, 25-27); Și fu daca săvîrşi Solomon zidind Casa Domnului... (вв, 3Împ, IX, 1-2); Și fu daca auzi Ierovoam, feciorul lui Navat, și el încă fiind în Eghipet (вв, 2 Imp, XII, 4-5).

As a result of these formal tribulations, dacă, by surpassing the other connectors in point of frequency, manages to become a typical conditional connector, but does not acquire a procedural meaning, as the polyvalence of the previous phases remains active.

However, the law of specificity of the reported ratio is required for the connector deci (cf. Gafton, 2011, p. 15-21), which was later assigned to the conclusive coordination. Surprisingly, the agglutination with the intensive semiadverb și, imposes a specific connector, deși. Surprising is the fact that, in conditional, the connector formed by agglutination was not imposed by the procedural meaning, whereas in the concessive, where there are more than 5 specific connectors, it was. Much more when the composition through agglutination was not achieved in the concessive relation.There are recorded by DVL the subsequently non-validated formations of the literary language (macarcare, macarcine, macarunde). It was also shown that: "Măcar că este adesea înregistrat în gramaticile de la sfîrșitul secolului al XVIII-lea ca o unitate sudată” (Zafiu, 2015, p. 681): macarché, macarque, mecarquo...

4.2. As it has been shown, a circumstantial relationship is characterized at a complex sentence level by a correlative structure, the resumption being usually made with a full semantic adverb, which dominates the substituting class of the respective adverbial modifier at the sentence level. The correlation between protasis and apodosis is made in the case of the two syntactic relations through several adverbs (cf. Avram, 1960, p. 153-201). But, surprisingly, among the correlative adverbs, very frequent are the adversative conjunctions. Referring to the concessive, it was shown: "A relationship of the same kind can also be expressed by a bipropositional structure with terms of the same rank coordinated by dar or ins $\breve{a}(. .$.$) Deși$ nu este cuminte, îl iubește toată lumea - Nu este cuminte, dar/însă îl iubește toată lumea" (GALR II, p. 592). The adversative correlatives, in old Romanian, but also in the current popular language (according to the frequently quoted example: Deși ești diavol, dar ți-e mintea goală), are also found after the conditional protasis.

There may be given many examples: De vorfipăcatele voastre intunecate sau de vor ficrunte ca singele, iar eu le voi face ca lîna cea albă (INB, I, 51/2-3); De nu ne veți da, iar noi vom lua și făr'de voia voastră (INB, I, 22/13-14); deaca muri unul pentru toți, iară toți am fost morți (NTB, 1Cor, 5, 15); Că de ar fi fost jidoveaște scrisă, dară cine o ară fi întors greceaște, cu adevărat nime nu ști (NT B, Mt, Pred., 119); De voi intrista eu pre voi, dară cine iaste să mă veselească (NTB, Cor, 2, 2); de-l vor vedea că ieste pre moarte, iară ei să-l călugărească (GU, 100, b/31-32); De ai uitat tu, dar eu n-am uitat (IN, 277, b/9-10).

Equally many examples can be given also for the concessive clause, with most types of connectors: $\boldsymbol{s} \breve{a}$ și n-avămu a trupului boală, iară inima noastră de pururea epăzită ( $\left.\mathrm{CC}^{2}, 433 / 17-18\right)$; Măcar de-și învăţa și-i certa, iar cu toiagul nu vrea să-i bată (INB, I, 24/20-21); Că omul, deși cunoscu el însuşi păcatul și vina sa, iar Dumnezeu tot îl lăsă să fie încorunat (INB, I, 12/4-5); de am și cunoscut trupește pre Hristos, iară acum nu-l mai cunoaștem (BB, 2Cor, 5, 16); săva că mulți cărtulari țin așea, că-i scrisă jidoveaște, iară mai mulți să îndoiesc (NTB, Pred., 119); Săvai că înșiş de sine și nu știu svinții de noişi de rugămintea noastră, iară după darul lui Dumnezeu (...) toate le știu (Vo, 28 r , 3-5); Săvai că poate zice neștine că să află și aici letopisețe, ci răspunsul îi iaste gata (ITR, $\left.3^{\mathrm{r}} / 10-11\right)$; Ci măcar că deodată au alinat lucrul, iară mai apoi Dispot de isnoavă mai bine s-au gătit (GU, 88, a/21-22); că măcar că lovisă și pe Cantemir paşea, iară leşii (...) răsipă acestor orde a face n-au putut (MC, 171, b/22-23); macar că cu chinuri și dureri, însă suffere și priimește (CI, 50/1-2); macar că viderea ochilor mai ascuţită s-au păzit, însă neştiința în întunerecul și în tartarul necunoștinții i-au vîrît (CI, 63/22-23); măcar că din fire orb și slut era, însă fietecarile (...) îl indemna (CI, 144/7-8); măcară că la mai multe n-au nemerit, de a grăi de firile lor adevărul, iară încăş destul că tot am pomenit (ITR, $\left.1^{\mathrm{v}} / 12-13\right) \ldots$

The fact that the phenomenon is so extensive, being encountered even in "official" texts (NTB, BB), shows that it was in the norm of the epoch for a long time. 
It is possible that, in the course of time, from the religious texts to have passed in the popular language: Deși ești diavol, dar ți-e tigva goală (apud Graur, 1956, p. 130); Căruța lui, deși era ferecată cu teie, cu curmeie, însă era o căruță bună (apud Graur, 1956, p. 130); Chiar dacă-i ea mai urîtă, da vorba aia, am pămînt, am ce munci (apud Teiuș, 1980, p. 125).

Trying to explain the ratio of the semantic implication, grammarians could not overcome the traditional formalisms, establishing, only for the concessive clause, the existence of coordination between the main clause and the subordinate one (Graur, 1956, p. 130; Avram, 1960, p. 212).

In order to find an accord, several arguments were invoked: the comparison with the typical correlative adverbial structure of the type acolo..., unde; the synonymy between the concessive relationship and the adversative coordination, justifying the interference by a presumed relation of interdependence: the psychological subject (the concessive clause) - the psychological predicate (the main clause) (Dragomirescu, 1984, p. 527). It was even shown that, by expressing contrasting contents, the procedural meaning of the adversative connectors coincides with that of the concessive connectors, progressing from the semantic contrast to the contradiction of the expectations (Zafiu, 2005, p. 247). The latter argument does not regard the simultaneous usage of the concessive and the adversative connectors, but it highlights the semantic specificity.

The circumstantial correlation imposes that the adverb has a syntactic function, which happens in the concessive correlation (chiar dacă..., totuşi), but it does not happen in the case of the adversative conjunctions.

The concessive-adversative synonymy, as demonstrated by the current pragmatics studies, is real, but the adversative correlatives are also found in the conditional period, that grammarians do not usually speak about.

For the concessive clause, the surprise came from the discovery of some statements in the current language (other than the popular language), in the language of the press (Eu, deși mă bucuram cînd izbuteam ceva, dar în conștiința mea socoteam...) or in translations (Deși au făcut același lucru, însă erau conduşi de alte scopuri) (cf. Zafiu, 2005, p. 247).

In the nineteenth century, the adversative correlation of the concessive and conditional clauses went into regression (cf. Merlan, 2001, p. 183).

The phenomenon was described with other "arguments": "an anomaly in the syntax of the contermporary Romanian language (...), disputable from the point of view of the cultivation of language (...) can not be tolerated"; "an aberrant addition of the coordinating conjunctions (...) creating an unpleasant anacoluthon"' (Dragomirescu, 1984, p. 526), etc.

In old Latin and in the popular one, the two types of implication from the subordinate to the main clause (the conditional and the concessive) were considered and constructed as the main clauses, "constituting perhaps an Indo-European heritage" (Iordache, 2002, p. 44). In another phase of evolution,for protasis (a false main clause), the classical Latin resorted to subordinate conjunctions (p. 66). The conditional clause passed through the same phases, from the false main clause to a hypotactic relationship, the similar behaviour being justified by the "logical and grammatical relationships between conditional and concessive clauses" (p. 116). Consequently, the main (false) conditionals and the concessives started to coexist with the respective subordinates not only in Romanian but also in the other Romance languages (p. 98).

Because popular Latin facts are difficult to be identified, the phenomenon can be "modeled" for the concessive relation also through classical Latin, in which the two processes, as it was shown, coexisted.

Thus, the correlative adverb tamen (cf. Rom. totussi) that marked the opposition ("the contradiction of expectations") from the "coordination" period was frequently preceded by coordinating conjunctions: et/at, sed, verum (et tamen = și totuşi; sed/verum tamen = dar totuşi $)($ Iordache, 2002, p. 46; cf. also Guțu, 2003, p. 1312; cf. also Ernout \& Meillet, 1994, p. 674).

Of these coordinating connectors, et was not adversative, so it could rarely render the concessive period (cf. Rom. Să-mi dai un milion și nu te las): therefore, the law of preserving the exceptions was 
also applied this time. Otherwise, it was associated with the semiadverb of a totalitarian meaning tot (si tot, totuşi), imposing itself in the literary norm with a procedural concessive meaning (cf. Ragea, 2010, p. 279).

Sed and verum, the adversative coordinating conjunctions, due to their oppositional meaning (cf. also Niculescu, 1965, p. 102: "the concessive conjunctions...many grammatical handbooks placed them amoung the adversative ones"), could express also alone the conditional and concessive implication, which, as seen from the examples, happened in Romanian language for a long period of time, to the perplexity of some grammarians. Only that in a totally particular way, starting from the old Romanian language, the concessive relation has built up a large number of specific connectors (with a procedural meaning), so that it could dispense of the contribution of the adversatives that had a mitigated meaning of the force of the focalizers.

4.3. Another similarity between the conditional and the concessive relationship is that of their organization in the form of grammatical periods, as an expression of a reasoning that involves exercising the analytical capacity of thought. The conditional period and, to a greater extent, the concessive period is not carried out by the automatisms that ensure the fluency of language, but there are statements for which thought is summoned. The protasis announces a meaning that the apodosis reverses (the concessive) or confirms (the conditional). Completing each other, they have a finite, closed semantic content, hence the impression of circularity from which their denomination comes (Gr. periodos $=$ drum ocolit).

As the analytical ability of the speakers was practiced at the level of the natural language, from the syntactic periods, they passed to the oratory periods by using some more refined procedures: parallelism, amplification, repetition, circularity... (cf. Munteanu, 1998, p. 77-78).

In old Romanian language, this was done, most of the time, through translation exercise, the incidence of the periodic features being quite reduced: E s-ară neștine zice că iubeaște Dumnezeu, e fratele său nu iubeaște, minciună iaste și, amu, să nu iubire fratele său ce-l veade e Dumnezeu ce nu-l veade cum să-l poată iubi? (св-СР, 365/3-5); Că de nu ne vămu pocăi și de nu ne vămu delunga de hitleniile noastre și de nedereptăți și bunătățile nu ne vămu nevoi să le facemu, avămu a peri dreptului judecătoriu și mîniei lu Dumnezeu (cc $\left.{ }^{2}, 234 / 8-11\right)$.

The concessive periods are rarer and more extensive, being more difficult to be closed: $E$ s-amu $f$ și goniți de nescare oameni necredincioși, să ne-ară și spînzura și să ne-ară și sparge cu moarte grozavă, s-amu fi și ucişu și să ne-ară munci în toate chinurele cealea realele, pentru dumnezeiasca credințăă, iară noi de acealea să nu ne întristămu, ce mai vîrtosu să ne bucurămu (cC² , 128/19-24).

The amplification in Cantemir, graphically signaled by brackets, becomes a caricatural procedure, the author being concerned not with the closure of the meaning, but with its dissipation: Măcară cum mai mult dobitoacelor cu patru picioare asemănîndu-te (precum singură tu cu al tău cuvînt ți-ai legat) (căci la cel cunoscătoriu mai tare să ține și iaste legătura hireşului cuvînt decît frenghiia întreită de la altul înfăşurată), mai mult în cumpăna dobitoacelor greuimea dreptății să pleci și după fățărnicia priinții, iară nu dupăpohta dreptățiii, giudecata să abați (CI, 21/11-17).

However, Antim Ivireanul, in competition with Hrisant Notaras from Brîncoveanu's court, owned the real art of oratory, exerting various argumentative and persuasive strategies (cf. Guia, 2014, p. 235; cf. also Guia, 2002-2004, p. 340): și măcar că eu am fost mai mic și mai netrebnic decît toț... dară Dumnezeu n-au căutat la micşorarea și netrebniciia mea, nu s-au uitat la sărăciia mea și streinătatea mea, n-au socotitprostiia și neștiințta mea, ci au căutat la noianul bunătății sale și au acoperit de cătră oameni toate spurcăciunile și färdelegile mele, care sînt mai multe decît perii capului mieu și decît năsipul mării și m-au înălțat, nevrednic find, la această stepenă și mare vrednicie a arbieriei (AI, 5\% /25-34).

The syntactic periods (the conditional and the concessive) contributed to the exercise of the analytical capacity of thinking. As they moved into the automatisms of speech by assuming the procedural meanings of the connectors, they made it possible to involve the affective components as a vector of persuasion in the rhetorical periods. 


\section{Conclusions}

The approach of the two modalities of manifestation of the hypothetical-deductive or conditional reasoning via the conditional and concessive periods focused on the basic connectors of the two syntactic positions at the complex sentence level, highlighting the way in which Romanian language has improved over time the syntactic instruments for expressing the three dimensions (real, hypothetical and unreal) of a complex message.

The conditional values, because they corresponded to the direct reasoning, although they experienced a great number of attempts / variants, failed to reach the procedural meaning by using only a single connector ( $\hat{i n} c a z c \breve{a}$ ), the rest of them remaining in the sphere of polyfunctional connectors.

Not the same thing happened with the concessive connectors. The difficulty of the semantic paradox led the speakers to several attempts, to the development of a focal system, consisting in intensive semiadverbs, in order to establish as clearly as possible the semantic nucleus of concessivity. The result was the acquiring of the procedural meaning for a much greater number of connectors: the largest number of specialized connectors for a syntactical position. This was possible by activating, in norms, the relationship between continuity and creativity.

\section{Bibliography}

\section{A. Studies}

Arvinte, V. (2004). Normele limbii literare în Biblia de la București (1688), Editura Universităţii “Alexandru Ioan Cuza”, Iaşi.

Avădanei, Șt.., Călinescu, Al., Ciopraga, M. \& Panaitescu, V. (1994). Terminologie poetică și retorică, Editura Universității "Alexandru Ioan Cuza", Iași.

Avram, M. (1960). Evoluția subordonării circumstanțiale cu elemente conjuncționale în limba română, Editura Academiei, București.

Barbu, N.I. (1943). Sintaxa limbii române după metoda istorico-stilistică, Editura Gina, București.

Bujor, I. \& Chiriac, Fr. (1971). Gramatica limbii latine, Editura Științifică, București.

Căpăţînă, C. (2007). Sintaxa limbii române, Editura Universitaria, Craiova.

Ciorănescu, Al. (2001). Dicționarul etimologic al limbii române, Editura Saeculum, București.

DELLR = Dictionnaire des emprunts latins dans les langues romanes, Editura Academiei, București, 2004.

Densusianu, Ov. (1961). Istoria limbii române, II, Editura Științi̧ică, București.

DLRLC = Dicționarul limbii române literare, contemporane, I, Editura Academiei, București, 1955.

Dominte, C. (2003). Negația în limba română, Editura FRM, București.

Drăganu, N. (1945). Elemente de sintaxă a limbii române, Institutul de Lingvistică Română, București.

Dragomirescu, Gh.N. (1975). Mică enciclopedie a figurilor de stil, Editura Științifică și Enciclopedică, București.

Dragomirescu, Gh.N. (1984). „Coordonarea adversativă" a concesivei cu regenta ei, in LR, XXXIII, p. 526-530.

Ernout, A. \& Meillet, A. (1964). Syntaxe latine, Klincksieck, Paris.

Ernout, A. \& Meillet, A. (1994). Dictionnaire étymologique de la langue latine. Histoire des mots, Klincksieck, Paris.

Frâncu, C. (1977). Formarea și evoluția complementului concesiv in limba română, in SCL, XXVIII, nr. 1, p. 15-26.

Frâncu, C. (2000). Conjunctivul românesc și raporturile lui cu alte moduri, Casa Editorială Demiurg, Iași.

Frâncu, C. (2009). Gramatica limbii române vechi (1521-1780), Casa Editorială Demiurg, Iași.

Gafton, Al. (1999). Su alcuni valori della congiunzione deca in alcune versioni dell' Apostol del secolo XVI, in AUI, II, p. 95-102.

Gafton, Al. (2001). Evoluția limbii române prin traduceri biblice din secolul al XVI-lea. Studiu lingvistic asupra Codicelui Bratul, in comparație cu Codicele Voronețean, Praxiul Coresian şi Apostolul Iorga, Editura Universității “Alexandru Ioan Cuza”, Iași.

Gafton, Al. (2011). Donc, in "Langue et litterature. Repères identitaires en contexte européen", nr. 8, p. 15-21.

GALR II = Guțu Romalo, V. (coord.) (2008). Gramatica limbii române, II. Enunțul, Editura Academiei Române, București.

Graur, Al. (1956). Pentru o sintaxă a propozițiilor principale, in vol. Studii de gramatică, I, Editura Academiei, București.

Guia, S. (2002-2004). Strategii argumentative în Didabiile lui Antim Ivireanul, în „Analele științifice ale Universității Alexandru Ioan Cuza", secțiunea Literatură, tomul XLVIII-L, p. 136-150.

Guia, S. (2014). Discursul religios. Structuri și tipuri, Editura Universității “Alexandru Ioan Cuza”, Iași.

Guțu, Gh. (2003). Dicţionar latin-român, Editura Humanitas, București.

ILRA = Sala, M. \& Ionescu-Ruxăndoiu, L. (coord.) (2018). Istoria limbii române, I, Editura Univers Enciclopedic Gold, București.

ILRL = Gheție, I. (1997). Istoria limbii române literare. Epoca veche (1532-1780), Editura Academiei, București.

Iordache, R. (2002). Exprimarea ideii de concesie in limba latină, Editura Paideia, București. 
Iordan, I. (1954). Limba română contemporană, Editura Universității, București.

Iordan, I. \& Robu, Vl. (1978). Limba română contemporană, Editura Didactică și Pedagogică, București.

Irimia, D. (2008). Gramatica limbii române, Editura Polirom, Iași.

Ivănescu, Gh. (2004). Curs de sintaxa limbii române moderne, Junimea, Iași.

MDA = Micul dicționar academic, II, D-H, Editura Univers Enciclopedic, București, 2002.

Merlan, A. (2001). Sintaxa limbii române. Relații sintactice și conectori, Editura Universității “Alexandru Ioan Cuza”, Iași.

Munteanu, Șt. (1998). Studii de lingvistică și de stilistică, Editura Pygmalion, Pitești.

Niculescu, Al. (1965). Individualitatea limbii române între limbile romanice. Contribuții gramaticale, Editura Științifică, București.

Ragea, O.A. (2010). Sensul procedural al conectorilor concesivi deși și totuşi, in Limba română: controverse, delimitări, noi ipoteze. Actele celui de-al 9-lea Colocviu al Catedrei de Limba Română, II. Secțiunea Pragmatică și stilistică, Editura Universității din București, București.

Riemann, O. (1932). Syntaxe latine d'apres les principes de la grammaire historique, Librairie Klincksieck, Paris.

SLR = Avram, M. (coord.) (2007). Sintaxa limbii române în secolele al XVI-lea-al XVIII-lea, Editura Academiei Române, București.

Slușanschi, D. (1994). Sintaxa limbii latine, II. Sintaxa frazei, Editura Universității din București, București.

Stan, C. (2013). O sintaxă diacronică a limbii române vechi, Editura Universității din București, București.

Teiuș, S. (1980). Coordonarea în vorbirea populară românească, Editura Științifică și Enciclopedică, București.

Tiktin, H. (1945). Gramatica română. Etimologia și sintaxa, Editura Tempo, București.

Trandafir, Gh.D. (1996). Alte probleme controversate de gramatică a limbii române actuale și de lingvistică generală, Editura Universității din Craiova, Craiova.

Wagner, R.L. (1966). Grammaire du français classique et moderne, Hachette, Paris.

Zafiu, R. (2005). Conjuncțiile adversative în limba română. Tipologie și niveluri de incidență, in Pană Dindelegan, G. (coord.), Limba română, Structură și funcționare, Editura Universității din București, București.

Zafiu, R. (2014). Stadii în gramaticalizarea conectorilor concesivi: tiparul conector condițional + focalizator în româna din secolele al XVI-lea - al XVII-lea, in Limba română: diacronie și sincronie în studiul limbii române, I. Gramatică. Fonetică și fonologie. Istoria limbii. Filologie, Editura Universității din București, București, p. 211-226.

Zafiu, R. (2015). Marcatorul concesiv măcar în diacronie (secolele al XVI-lea-al XVIII-lea), in vol. Inspre și dinspre Cluj, Contribuții lingvistice: omagoi profesorului G. G. Neamțu la 70 de ani, Editura Scriptor și Editura Argonaut, Cluj-Napoca, p. 678-687.

\section{B. Sources}

A = Alexandria, Studiu introductiv, ediție și glosar de Florentina Zgraon, Fundația Națională pentru Știință și Artă, București, 2006.

AB = Istoria Țării Românești (Anonimul Brîncovenesc), Ediție întocmită de Constantin Grecescu, Editura Științifică, București, 1959.

AI = Antim Ivireanu, Opere, Ediție critică și studiu introductiv de Gabriel Ștrempel, Editura Minerva, București, 1972.

Bв = Biblia adică Dumnezeiasca Scriptură a Vechiului și Noului Testament, Editura Institutului Biblic și de Misiune a Bisericii Ortodoxe Române, București, 1988.

Св = Codicele Bratul, Ediție de text de Alexandru Gafton, Editura Universității “Alexandru Ioan Cuza”, Iași, 2003.

$\mathrm{CC}^{2}=$ Carte cu învățătură (1581), publicată de Sextil Pușcariu și Alexie Procopovici, Atelierele Grafice Socec \& Co., București, 1914.

CD = Dimitrie Cantemir, Opere (Divanul), Ediție Stela Toma, Virgil Cîndea, Nicolae Stoicescu, Editura Academiei Române, Univers Enciclopedic, 2003.

CI = Dimitrie Cantemir, Opere (Istoria ieroglifică), Ediție Stela Toma, Virgil Cîndea, Nicolae Stoicescu, Editura Academiei Române, Univers Enciclopedic, 2003.

Cs = Codex sturzanus, Studiu filologic, studiu lingvistic, ediție de text și indice de cuvinte de Gheorghe Chivu, Editura Academiei Române, București, 1993.

$\mathrm{CT}=$ Tetraevanghelul lui Coresi, Ediție de Florica Dimitresccu, București, 1961.

CV = Codicele voronețean, Ediție critică, studiu filologic și studiu lingvistic de Mariana Costinescu, Editura Minerva, București, 1981.

$\mathrm{DVL}=$ Dictionarium Valachico-Latinum. Primul dicționar al limbii române, Ediție de Gh. Chivu, Editura Academiei, București, 2008.

F = Fiziologul. Archirie și Anadan, Ediție de V. Guruianu, Magdalena Georgescu, Editura Minerva, București, 1997.

FD = Floarea darurilor, în vol. Floarea darurilor. Sindipa, Ediție de Alexandra Moraru, Magdalena Georgescu, Editura Minerva,

București, 1996.

GU = Grigore Ureche, Letopisețul Țării Moldovei, Ediție de Tatiana Celac, Editura Hyperion, Chișinău, 1990.

IN = Ion Neculce, Letopisețul Țării Moldovei, Ediție de Tatiana Celac, Editura Hyperion, Chișinău, 1990. 
INB = Învățăturile Sfîntului Voievod Neagoe Basarab către fiul său Theodosie, Ediție Dan Zamfirescu, Editura Roza Vînturilor, București, 2010.

ITR = Istoriia Țărîi Rumînești, atribuită Stolnicului Constantin Cantacuzino, Ediție critică, studiu filologic, studiu lingvistic, glosar și indice de nume proprii de Otilia Dragomir, Editura Academiei Române, 2006.

MC = Miron Costin, Letopisețul Țării Moldovei, Ediție de Tatiana Celac, Editura Hyperion, Chișinău, 1990.

MO = Mihail Moxa, Cronica universală, Ediție critică, însoțită de izvoare, studiu introductiv, note și indici de Gheorghe Mihăilă,

Editura Minerva, 1989.

NTB = Noul Testament (1648), Editura Episcopiei Ortodoxe Române, Alba Iulia, 1988.

PH = Psaltirea Hurmuzaki, Studiu filologic, studiu lingvistic și ediție de Ion Gheție și Mirela Teodorescu, Editura Academiei Române, 2005.

PO = Palia de la Orăştie (1682), Text stabilit și îngrijire editorială de Vasile Arvinte, Ioan Caproșu și Alexandru Gafton, Editura Universității „Alexandru Ioan Cuza”, Iași, 2005.

Prav.1581 = Pravila ritorului Lucaci, Ediție Ion Rizeacu, Editura Academiei Române, București, 1971.

RG = Radu logofătul Greceanu, Istoria domniei lui Constantin Basarab Brîncoveanu voievod (1688-1714), Studiu introductiv și ediție critică întocmite de Aurora Ilieș, Editura Academiei Române, 1970.

S = Sindipa în vol. Floarea darurilor. Sindipa, Ediție de Alexandra Moraru, Magdalena Georgescu, Editura Minerva, București, 1996.

SOR = Pană Dindelegan, G. (coord.) (2016). The Syntax of Old Romanian, Oxford University Press, Oxford.

TE = Coresi, Tîlcul evangheliilor și Molitevnic rumînesc, Ediție critică de Vladimir Drimba, cu un studiu introductiv de Ion Gheție, Editura Academiei Române, București, 1998.

$\mathrm{TL}=$ Théatre latin, Plaute, Térence, publiés par Georges Ramain, Librairie Hachette, Paris, 1897.

Vo = Varlaam, Opere, Răspunsul împotriva Catihismului Calvinesc, Ediție critică, studiu filologic și studiu lingvistic de Mirela Teodorescu, Editura Minerva, București, 1984.

VO = Varlaam, Opere, Carte românească de învățătură, Răspunsul împotriva Catihismului Calvinesc..., Alcătuire, transcriere a textelor, note și comentarii, glosar și bibliografie de Manole Neagu, Editura Hyperion, Chișinău, 1991. 